\title{
Targeting expression of a dominant-negative retinoic acid receptor mutant in the epidermis of transgenic mice results in loss of barrier function
}

\author{
Sumihisa Imakado, ${ }^{1,2}$ Jackie R. Bickenbach, ${ }^{1}$ Donnie S. Bundman, ${ }^{1}$ Joseph A. Rothnagel, ${ }^{1}$ \\ Paul S. Attar, ${ }^{1}$ Xiao-Jing Wang, ${ }^{1}$ Vincent R. Walczak, ${ }^{3}$ Stephen Wisniewski, ${ }^{3}$ Jeffrey Pote, $^{3}$ \\ Joel S. Gordon, ${ }^{3}$ Richard A. Heyman, ${ }^{4}$ Ronald M. Evans, ${ }^{5}$ and Dennis R. Roop ${ }^{1,6}$ \\ ${ }^{1}$ Departments of Cell Biology and Dermatology, Baylor College of Medicine, Houston, Texas 77030; ${ }^{3}$ SHWW R,D, \& E, \\ Applied Research, Johnson \& Johnson, Skillman, New Jersey 08558; ${ }^{4}$ Ligand Pharmaceuticals, San Diego, California 92121 ; \\ ${ }^{5}$ Gene Expression Laboratory, Howard Hughes Medical Institute, The Salk Institute for Biological Studies, La Jolla, \\ California 92037 USA
}

To study the effects of retinoic acid on the skin in vivo, we have subverted the activity of endogenous receptors by targeting expression of a dominant negative mutant of retinoic acid receptor $\alpha(R A R \alpha)$ to the epidermis of transgenic mice. At birth, mice expressing the mutant RAR $\alpha$ transgene exhibited a marked phenotype of a red, shiny skin that was somewhat sticky to touch. Severely affected neonates died within 24 hr. Histological changes in the epidermis were subtle with the phenotypic stratum corneum appearing slightly thinner and more loosely packed than in controls. Electron microscopic studies revealed that lipid multilamellar structures were not present between cells in the stratum corneum of phenotypic mice. When assayed for transepidermal water loss, phenotypic skin lost water at a rate three times faster than controls, suggesting that neonatal lethality resulted from loss of epidermal barrier function. The absence of a functional lipid barrier in transgenic mice first became evident at E17 when lipids were extruded initially into the intercellular space. We have identified a potential pathway linking inhibition of retinoid signaling with disruption of the lipid barrier that involves peroxisome proliferator-activated receptors. This study documents the role of the retinoid signaling pathway in formation and maintenance of a functional epidermis and provides the first evidence that this is mediated in part by modulation of lipid metabolism.

[Key Words: RAR $\alpha$; lipid; epidermis; transgenics, PPAR]

Received October 20, 1994; revised version accepted December 15, 1994.

Retinoids have been shown to have dramatic effects on epithelial differentiation. This is most evident for internal lining epithelia. For example, depleting a secretory epithelium of retinoids causes squamous metaplasia, conversion to a squamous epithelium (Wolbach and Howe 1925). The reverse is also true; an excess of retinoids causes mucous metaplasia, the conversion of a stratified squamous epithelium to a secretory epithelium (Smith 1973). Although the epidermis is also responsive to retinoids, the response is somewhat different depending on whether assayed in vitro or in vivo. In vitro, removal of vitamin A from epidermal keratinocyte culture medium induces terminal differentiation, whereas the addition of retinoids suppresses differentiation (Yuspa and Harris 1974; Fuchs and Green 1981;

Present address: ${ }^{2}$ Tokyo University Hospital, Department of Dermatology, 7-3-1, Hongo, Bunkyo-ku, Tokyo, 113, Japan.

${ }^{6}$ Corresponding author.
Green and Watt 1982). In addition, retinoids prevent the induction of terminal differentiation markers in keratinocytes induced to differentiate by $\mathrm{Ca}^{2+}$ (Roop et al. 1987; Hohl et al. 1991). In vivo, excessive exposure of humans to retinoic acid, either in the form of hypervitaminosis $\mathrm{A}$ or excessive ingestion of retinoic acid, leads to thinning of the epidermis and drying of the skin, whereas vitamin A deficiency produces hyperkeratosis of the skin (for review, see Davies et al. 1992). In addition, acute or chronic topical treatment of normal human skin with pharmacological levels of retinoic acid causes epidermal thickening and altered expression of some, but not all, of the differentiation markers that are affected by retinoids in cultured keratinocytes (Rosenthal et al. 1992).

Such physiological effects of retinoids are mediated by two types of receptors, the retinoic acid receptors (RAR $\alpha$, RAR $\beta$, RAR $\gamma$ ) (Petkovich et al. 1978; Giguere et al. 1987; Brand et al. 1988) and the retinoid $X$ receptors $(R X R \alpha$, RXR $\beta$, RAR $\gamma$ ) (Mangelsdorf et al. 1990, 1992; Leid et al. 
1992). These proteins, which are members of the nuclear receptor superfamily of ligand-dependent transcription factors, regulate patterns of gene expression in target tissues (Evans 1988; Green and Chambon 1988). Both RARs and RXRs bind 9-cis RA with high affinity; however, only the RARs bind all-trans retinoic acid (Heyman et al. 1992; Levin et al. 1992). Although it was thought previously that both RARs and RXRs function as homodimers, evidence now indicates that RARs, like the receptors for thyroid hormones (TRs), vitamin D (VDR), and peroxisome proliferators (PPARs), require heterodimerization with RXRs for effective DNA binding and function (Yu et al. 1991; Kliewer et al. 1992a,b; Leid et al. 1992; Marks et al. 1992; Zhang et al. 1992). In the epidermis, the major isoforms expressed are RAR $\gamma$ and RXR $\alpha$, with lower levels of RAR $\alpha$ (Elder et al. 1991). The exact roles of these receptors in eliciting the various effects of retinoids on the epidermis have not been established. One approach to solving this problem is to generate mice deficient in receptor function.

Previous transgenic approaches to interfere with the retinoid signaling pathway have produced mice, using homologous recombination in mouse embryonic stem cells, that are null for either RAR $\alpha$ (either RAR $\alpha 1$ or all isoforms) (Li et al. 1993; Lufkin et al. 1993) or RAR $\gamma$ (either RAR $\gamma 2$ or all isoforms) (Lohnes et al. 1993). These mice demonstrated growth deficiency, early lethality, squamous metaplasia of the seminal vesicles and prostate (RAR $\gamma$ null), and degeneration of the testes (RAR $\alpha$ null); however, the epidermis appeared normal in both null models. These studies suggest that if retinoids are important in the development and maintenance of the epidermis, then there must be functional redundancy among the RARs, and RAR $\alpha$ and RAR $\gamma$ can substitute for each other in the absence of the other. Recent success in targeting the disruption of the $\mathrm{RXR} \alpha$ gene resulted in embryonic lethality between embryonic day 13.5 (E13.5) and E16.5 (Kastner et al. 1994; Sucov et al. 1994). The potential effect of loss of function of $\mathrm{RXR} \alpha$ on epidermal development could not be assessed in the above studies because formation of a fully functional epidermis occurs just before (E18) birth (DuBrul 1972).

To circumvent problems with embryonic lethality and to increase the likelihood of observing effects of inhibition of the retinoid signaling pathway in an epithelium like the epidermis, which acquires its differentiated function late in development, we targeted expression of a dominant negative mutant of $\operatorname{RAR} \alpha \quad(R A R \alpha 403$ ) (Damm et al. 1993) with an epidermal-specific vector that is expressed initially at E15 (Greenhalgh et al. 1993a; Chung et al. 1994). Previous studies have demonstrated that this $\operatorname{RAR} \alpha$ derivative is a negative transcriptional regulator that can block wild-type RAR function, and in comparison to similar mutants derived for RAR $\beta$ and RAR $\gamma$, it was the most potent (Damm et al. 1993). This mutant is a truncated form of RAR $\alpha$ that retains the ability to dimerize and bind target DNA, but has lost its transcriptional activation function. Furthermore, because of its ability to heterodimerize with RXRs (Damm et al. 1993), this $\operatorname{RAR} \alpha$ mutant is also able to subvert activity of receptors for TRs, VDR, and PPARs. Thus, it is the ability to form inactive heterodimers that provides this mutant with its wide spectrum of potent dominant negative activity. Here we report the generation of transgenic mice that express RAR $\alpha 403$ exclusively in the epidermis and exhibit a severe skin phenotype resulting in neonatal lethality. This study documents the role of the retinoid signaling pathway in formation and maintenance of a functional epidermis.

\section{Results}

RAR $\alpha 403$ transgenic mice exhibit a marked skin phenotype at birth

To target expression of the dominant negative mutant of $\operatorname{RAR} \alpha($ RAR $\alpha 403)$, we used an epidermal-specific targeting vector that we had derived from regulatory sequences of the human keratin 1 (HKl) gene (Chung et al. 1994). The construction and characterization of this vector have been described previously /Greenhalgh et al. $1993 a, b)$. Figure la is a schematic of this vector containing the RAR $\alpha 403$ mutant (pHK1-RAR $\alpha 403$ ). The first pups to test positive for the transgene were found dead 10-24 hr after birth. To determine whether the pups were stillborn or died shortly after birth, we monitored litters at birth carefully, and observed several live-born, phenotypic pups in subsequent litters. These pups exhibited a phenotype of red, shiny skin that was somewhat sticky to touch (Fig. 1b). This phenotype ranged from severe to moderate in which the skin was less red and shiny. Eventually, 12 founder mice tested positive for the transgene, as judged by PCR analysis of their tail DNA. Of these 12 founders, four showed the severe phenotype. Although these mice were well fed by their mothers, all four severely affected pups died within $24 \mathrm{hr}$ after birth. One male without an obvious phenotype at birth tested positive for the transgene and survived to adulthood. This male was a mosaic, as he sired only four positive pups out of $135 \mathrm{~F}_{1}$ progeny; however, all four exhibited a severe phenotype. In the moderate cases, the phenotype was only evident for a day or two and the mice survived to adulthood. These founders produced several positive $F_{1}$ progeny that exhibited moderate phenotypes similar to their transgenic parents. Further matings to generate $F_{2}$ progeny resulted in pups with both severe and moderate phenotypes (the severe phenotypes died within $24 \mathrm{hr}$; the moderate phenotypes survived to adulthood). Pups exhibiting severe phenotypes most likely represent homozygotes and suggest a dosage effect from expression of RAR $\alpha 403$ (see below). We have observed previously an increase in phenotypic severity when other lines expressing HKl-driven transgenes are mated to homozygosity (Greenhalgh et al. 1993a).

\section{Expression of HK1-RAR 4403 in the epidermis}

To demonstrate expression of HK1-RAR $\alpha 403$, we isolated total RNA from the epidermis of transgenic and normal littermates and from the total skin of transgenic 


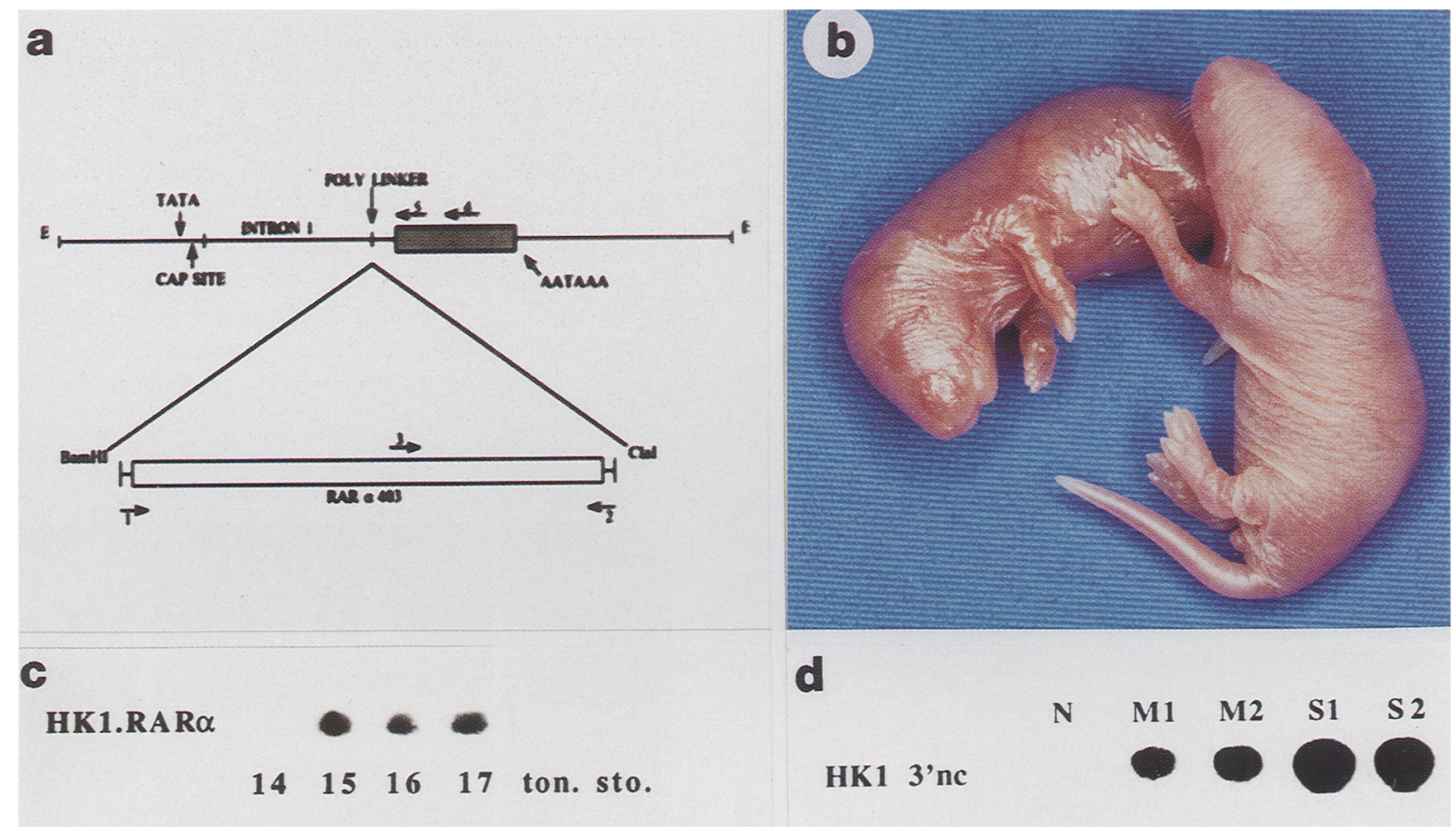

Figure 1. Transgene construct, RAR $\alpha 403$ phenotype, and transgene expression. $(a)$ Schematic drawing showing structure of the HK l-RAR $\alpha 403$ transgene. Construction and characterization of the HKl epidermal targeting vector have been described /Greenhalgh et al. 1993a,b). Using the dominant-negative mutant receptor RAR $\alpha 403$ as a template and oligonucleotides 1 and 2 , a PCR product was synthesized and inserted into the BamHI and $\mathrm{ClaI}$ sites of the vector polylinker. Oligonucleotides 3 and 4 were used for screening transgenic mice and oligonucleotides 3 and 5 were used for the reverse transcriptase PCR analysis. $(b)$ Gross appearance of severely phenotypic HK1-RAR $\alpha 403$ transgenic neonate (left) with normal littermate. (c) Analysis of HK1-RAR 403 transcripts in developing embryos, tongue, and stomach. Total RNA was subjected to reverse transcriptase PCR, then transferred to nitrocellulose and hybridized with ${ }^{32}$ P-labeled probe specific for the HKl-RAR $\alpha 403$ transgenc, and exposed to photographic film. (Lane 14) El4; (lane 15) El5; (lane 16) E16; (lane 17) E17. (ton.) Newborn tongue; (sto.) newborn stomach. (d) RNase protection analysis of epidermal RNA from mice exhibiting normal (N), moderate (M1 and $M 2)$, and severe $(\mathrm{S} 1$ and $\mathrm{S} 2)$ phenotypes.

and normal embryonic littermates. After preparing a cDNA template of these RNAs, specific primers were used to amplify cDNAs containing sequences corresponding to RAR $\alpha 403$ and the 3 ' noncoding region of the HK 1 vector (Fig. 1a). A 239-bp fragment was observed in samples from transgenic embryos of E15, E16, and E17, but not in those from embryos of E14, or in stomach or tongue from transgenic neonates (Fig. 1c). These results confirm that the transgene was only expressed in the epidermis and was not transcribed until E15. The expression characteristics of HK1-RAR $\alpha 403$ are identical to those observed for the $10.8-\mathrm{kb}$ fragment from which the HK1 vector was derived (Chung et al. 1994). RNase protection analysis confirmed that phenotype severity correlated with expression levels of the transgene (Fig. 1d).

\section{Histopathology of HK1-RAR $\alpha 403$ transgenic skin}

In general, normal mammalian epidermis consists of four layers of cells (Fig. 2). The first three layers are comprised of living, nucleated cells that differentiate and move in a programmed manner from the dermal-epidermal junction toward the outer layer of the epidermis. The fourth layer, the stratum corneum, is comprised of dense, flattened, enucleated cells called corneocytes. As corneocytes differentiate, adhesion to each other gradually diminishes, such that only the outer most cells are sloughed into the environment. The stratum corneum as a cohesive unit makes up the main water barrier between the organism and the environment. Histological examination of the epidermis from transgenic and normal mice showed that the number of nucleated cell layers and hair follicles were the same. However, close examination of the cells in the stratum corneum showed a subtle, but distinguishable difference. Normal stratum corneum consisted of cells that were so closely packed together that the whole stratum corneum appeared as one unit (Fig. 2a). In transgenic epidermis, the corneocytes were thinner and more loosely packed than normal, and in some cases, looked like dense individual ribbons of cells on top of the nucleated cell layers (Fig. 2b).

\section{HK1-RARa403 transgenic mice exhibit normal expression of differentiation markers, but aberrant expression of keratin $\mathrm{K} 6$}

Because previous studies demonstrated that retinoids could inhibit or alter epidermal differentiation, we as- 

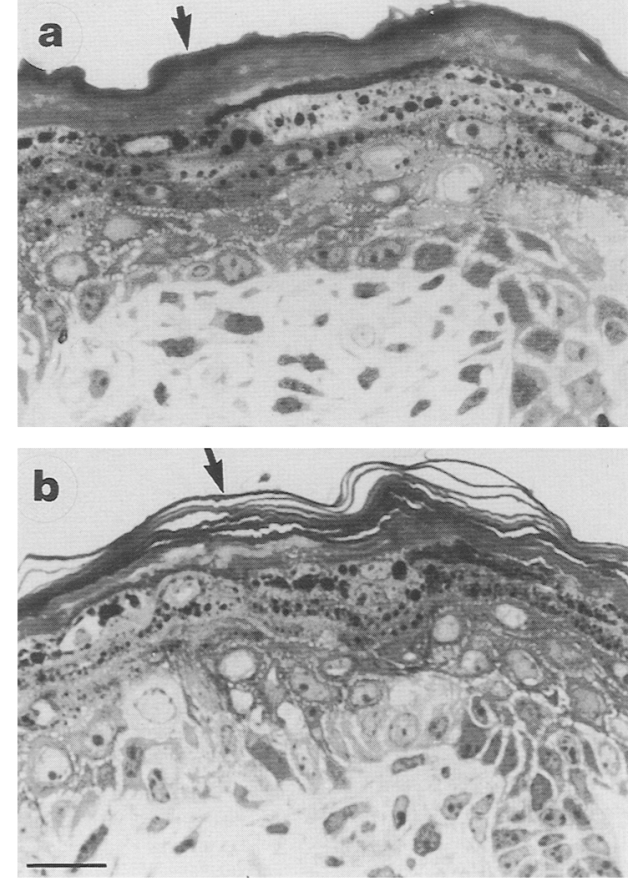

Figure 2. Histology of normal and transgenic epidermis. Note the thin and loosely packed corneocytes (arrow) in the transgenic stratum corneum $(b)$ as compared to normal (arrow) $(a)$. Bar, $20 \mu \mathrm{m}$.

sessed expression of several differentiation markers to determine whether there were any detectable changes in the differentiation program. Surprisingly, no significant changes were detected in the expression of keratins K5, $\mathrm{K} 14, \mathrm{~K} 1$, and $\mathrm{K} 10$ or in loricrin and filaggrin. Furthermore, to exclude that the epidermal differentiation program had begun to switch to that of an internal stratified epithelium, we assayed for expression of K13, a keratin normally associated with terminal differentiation of internal stratified epithelia (Nischt et al. 1988), but we failed to detect staining.

We then analyzed for expression of $\mathrm{K} 6 . \mathrm{K} 6$ is expressed normally only in the outer root sheath of hair follicles and not in the interfollicular epidermis (Fig. 3a). However, pups with a severe phenotype exhibited strong expression of $\mathrm{K} 6$ throughout the suprabasal layers (Fig. 3c). We have shown previously that $\mathrm{K} 6$ is induced in the epidermis of transgenic mice exhibiting a hyperplastic phenotype as the result of expressing ras $^{\mathrm{Ha}}$ (Greenhalgh et al. 1993a), fos (Greenhalgh et al. 1993b), or transforming growth factor- $\alpha$ (TGF- $\alpha$ ) (Dominey et al. 1993). Therefore, we assayed for changes in the mitotic activity of phenotypic skins by injecting neonates intraperitoneally with bromodeoxuridine ( $\mathrm{BrdU})$ followed by labeling with an anti-BrdU antibody. However, no differences were observed between normal and phenotypic epidermis. Although the induction of $\mathrm{K} 6$ and its coexpressed partner $\mathrm{K} 16$ has generally been shown to occur in hyperproliferative conditions (Weiss et al. 1984), recently we observed $\mathrm{K} 6$ expression in the growth-arrested epidermis of HK1-TGF $\beta_{1}$ transgenic mice (Sellheyer et al. 1993). On the basis of this result, we concluded that K6/K16 induction can occur in response to a variety of stimuli that may perturb normal keratinocyte biology.

In this regard, we noted that the expression of $\mathrm{K} 6$ in the moderate phenotypes was focal and occurred initially in the granular layer just beneath the stratum corneum (Fig. 3b), a pattern of expression unusual in comparison with our other transgenic lines, which exhibit K6 expression throughout the epidermis. This prompted us to examine $\mathrm{K} 6$ expression in transgenic epidermis
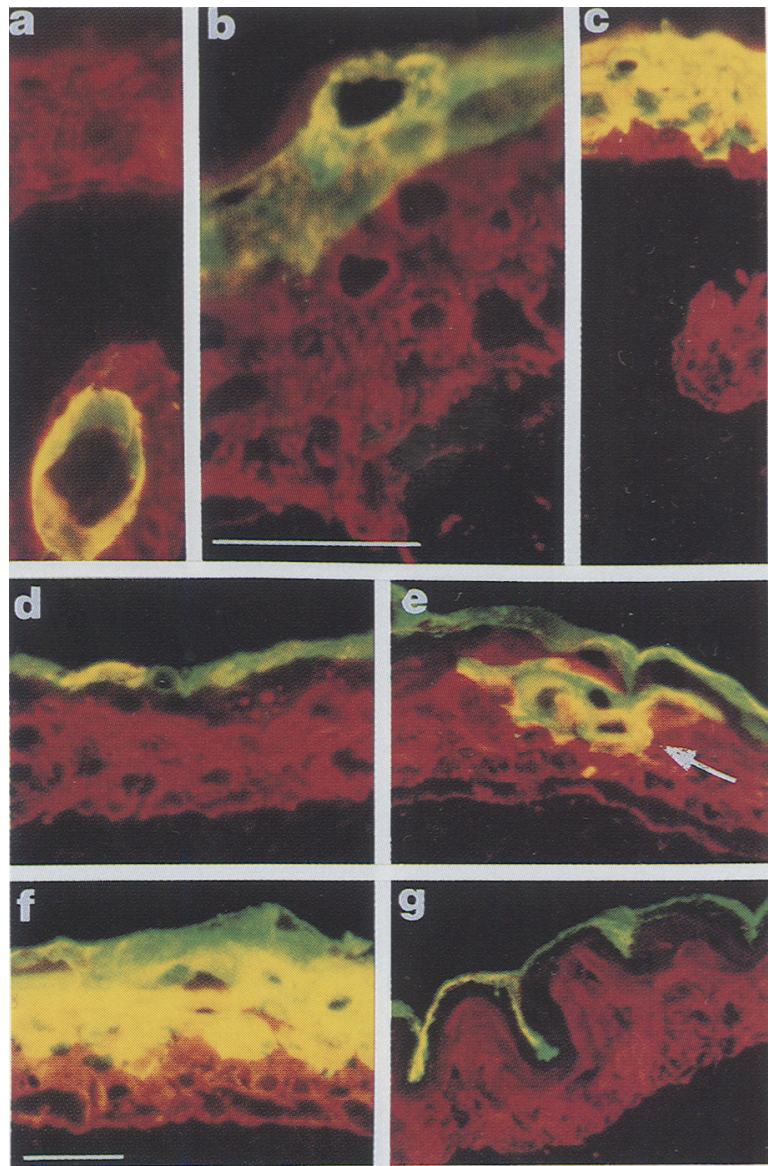

Figure 3. MK6 expression in neonatal and fetal HK1RAR $\alpha 403$ epidermis. All micrographs were double stained with fluorescein-labeled antibody to MK6 (green or yellow) and Texas red-labeled antibody to MK14 (red). (a) Skin from a normal littermate in which MK6 only stains in the hair follicles. $|b|$ Mildly phenotypic transgenic skin; note abnormal MK6 staining in a few granular cells. (c) Severely phenotypic transgenic skin; note MK6 staining extends throughout the granular and spinous layers of the epidermis. (d) Fetal skin from E16 transgenic embryo; note only periderm stains with MK6. $\{e\rangle$ Fetal transgenic skin from E17 embryo; note granular cells (arrow) abnormally stain with MK6. (f) Fetal skin from E18 transgenic embryo; note MK6 stains throughout the granular and spinous layers of the epidermis (cf. with c). (g) Fetal skin from E17 normal embryo; note that MK6 only stains the periderm. Bars, 30 $\mu \mathrm{m}$. 
during development. In normal fetal skin $\mathrm{K} 6$ is only expressed in the periderm layer. In mouse periderm it is present by E15, persists through development (Fig. 3g), and is present even when the periderm begins to slough at E18. An identical staining pattern was observed in E16 fetal transgenic epidermis (Fig. 3d). However, by E17, fetal transgenic epidermis exhibited patchy expression of $\mathrm{K} 6$ in a few granular cells (Fig. 3e), and by E18, K6 expression resembled that of neonatal skin with a severe phenotype (Fig. 3; cf. f with c). Although the RAR $\alpha 403$ transgene was expressed at E15 (see Fig. 1c), K6 was not induced in the epidermal layers until E17 (Fig. 3e). Thus, the expression of $\mathrm{K} 6$ is not in direct response to expression of RAR $\alpha 403$. E17 is the time during mouse development when the developing epidermis begins to take over the barrier function from the periderm, a single cell layer of protective epithelium covering the entire fetus (DuBrul 1972). One interpretation of these data is that the transgenic mice have a defective epidermal barrier. Because of the proximity of granular cells to the stratum corneum, they are the first to sense a break in the barrier, and the induction of $\mathrm{K} 6$ could occur as a result of this perturbation.

\section{HK1-RAR 403 transgenic mice exhibit a defect in epidermal barrier function}

To determine whether, in fact, the epidermal barrier function was defective, we compared transepidermal water loss (TEWL) in transgenic and normal epidermis. As shown in Figure 4, more water crossed the transgenic epidermis than the control epidermis. In addition, TEWL correlated directly with severity of phenotype, in that the severely phenotypic skin lost more water (approximately three times more than control) than the moderate phenotypic skin (which was not significantly different from controls). Thus, expression of the RAR $\alpha 403$

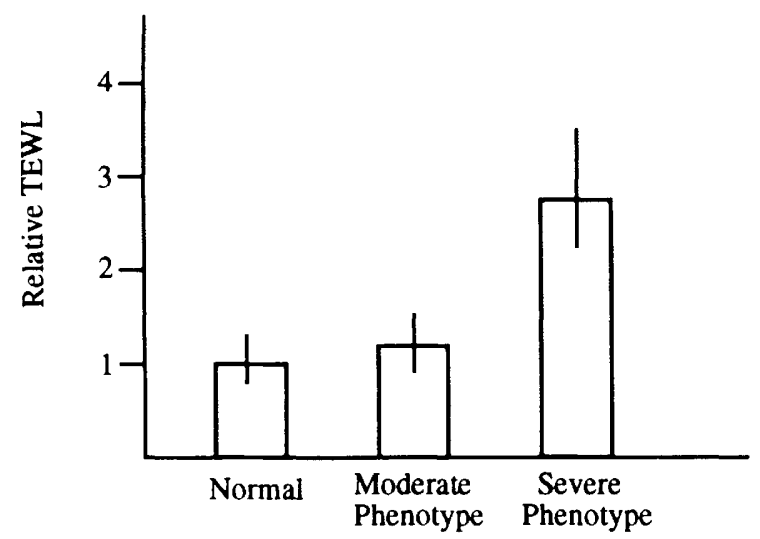

Figure 4. Transepidermal water loss (TEWL) from normal and phenotypic neonatal epidermis. Water loss was measured by removing the skins and sealing them across the aperture of a chamber containing $0.5 \mathrm{ml}$ of water and water loss measured gravimetrically for $72 \mathrm{hr}$. Normal, $n=16$; Moderate phenotype, $n=15$; Severe phenotype, $n=10$. dominant-negative mutation directly affected epidermal barrier function, and caused neonatal lethality in severe phenotypes.

\section{Loss of epidermal barrier function attributed to absence of lipid multilamellar structures}

The barrier function of the epidermis is maintained by its outer layer, the stratum corneum, which consists of lifeless squames composed of condensed keratin surrounded by a reinforced protein cell envelope (CE). The $\mathrm{CE}$ is a specialized structure formed beneath the plasma membrane of terminally differentiating keratinocytes (for review, see Hohl and Roop 1993; Reichert et al. 1993). This structure consists of a variety of proteins cross-linked by covalent bonds into a rigid scaffold with specialized lipids attached to its external surface (Wertz et al. 1989; Chang et al. 1993/ and a keratin filament/ matrix complex interacting with its internal surface (Steinert 1993). To examine the possibility that the decreased barrier function of the transgenic epidermis may be attributable to formation of abnormal CE, we isolated CE from phenotypic epidermis. Morphologically, these $\mathrm{CE}$ were identical to controls. Moreover, we determined that the amino acid composition of these CE was identical to that which we had determined previously for normal newborn mice (Mehrel et al. 1990). These results suggest that the protein component of the stratum corneum is normal, and are consistent with our failure to detect significant changes in the expression level of loricrin, a major CE component (Mehrel et al. 1990).

Because the CE appeared to be normal in phenotypic epidermis, we analyzed the other major component of the stratum corneum that contributes to barrier function (i.e., the lipid component). Electron microscopic examination of phenotypic epidermis revealed that the only morphological structure affected was the lipid multilamellar structure (Fig. 5). During differentiation, lamellar granules first appear in small numbers in the spinous cells and become most numerous in the granular layer, where they accumulate near the distal surface of the cells. Lipid vesicles or disks along with hydrolytic enzymes are packaged into the lamellar granules (Fig. 5a) (for review, see Wertz and Downing 1992), which extrude their contents into the intercellular spaces just before to the final stage of conversion from granular cell to corneocyte (Fig. 5c,e). These extruded lipid disks are fused enzymatically into intercellular multilamellar structures easily identified by electron microscopy as a series of electron-dense and electron-lucid layers (Elias and Friend 1975; Madison et al. 1987) (Fig. 5g). In the transgenic epidermis no multilamellar structures were observed between corneocytes (Fig. 5h); instead only amorphous "globs" were seen between the granular layer and the stratum corneum (Fig. 5f). Surprisingly, the lamellar granules seen in transgenic epidermis (Fig. 5b) were indistinguishable from those observed in normal littermates (Fig. 5a,c) and they extruded their contents normally (Fig. 5d); however, the extruded lipid disks (Fig. $5 \mathrm{~d})$ were not able to fuse into multilamellar structures. 
Figure 5. Electron microscopy of normal and HK l-RAR $\alpha 403$ neonatal epidermis. $|a|$ Lipid lamellar granule in the granular layer of normal epidermis. (b) Normal-looking lipid lamellar granule in transgenic epidermis. (c) Lipid lamellae (arrow) between upper two granular cells in epidermis from normal littermate. $(d)$ Lipid lamellar disks (arrow) extruded between granular cells in transgenic epidermis; note normal appearance. (e) Lipid lamellae (arrow) formed between granular and stratum corneum cells in normal epidermis. (f) Abnormal lamellar granules (arrow) at granular/stratum corneum junction in transgenic epidermis; note globular appearance and lack of normal lamellae. $(g)$ Multilamellar structure |arrow found between corneocytes in normal epidermis. $(h)$ Lack of any lipid multilamellar structure between outer corneocytes in transgenic epidermis. $(a-f)$ Bars, $100 \mathrm{~nm} ;(g, h) 250 \mathrm{~nm}$.
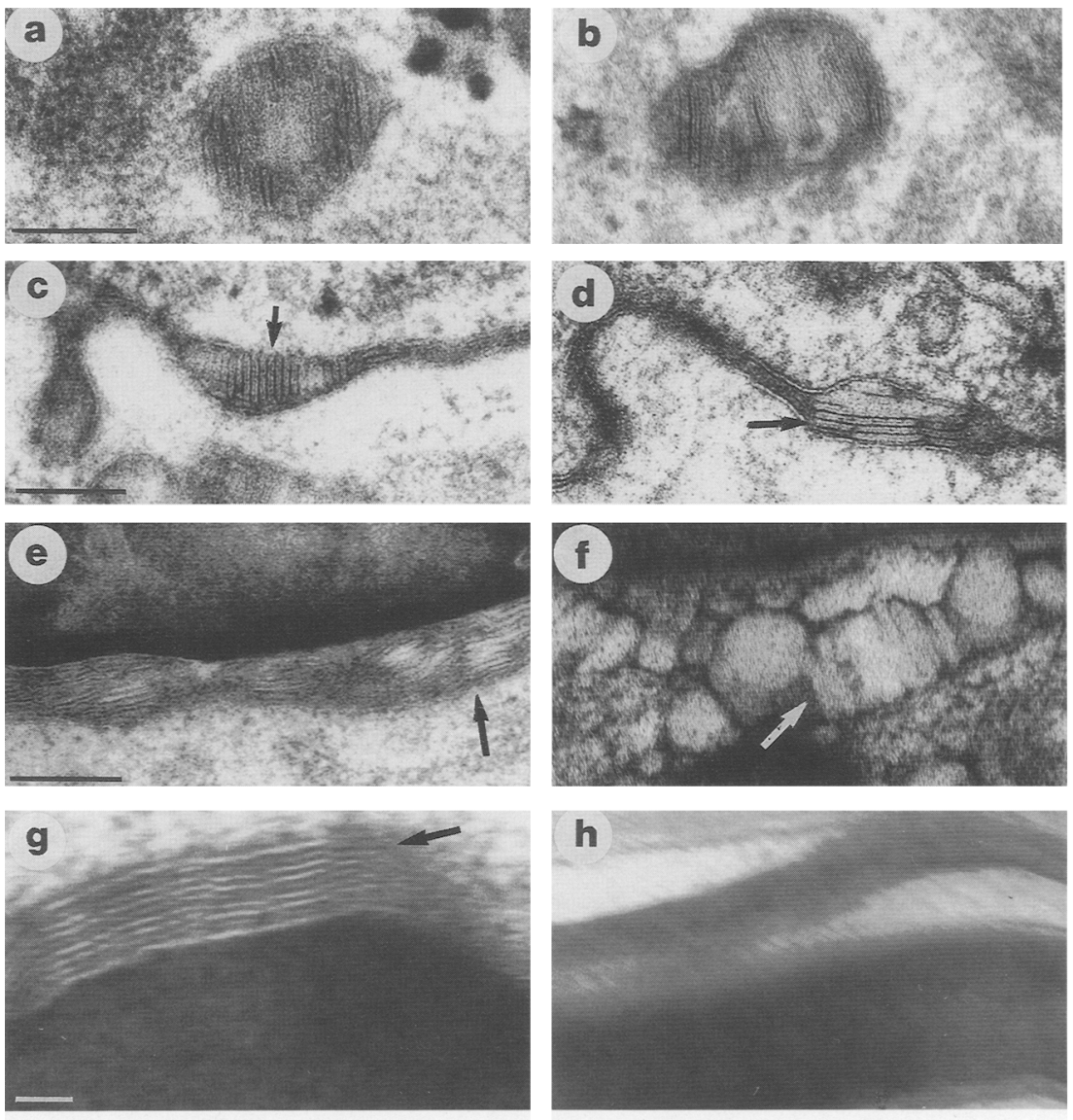

To determine whether the failure to form a multilamellar structure occurred initially in utero, we examined the epidermis from developing embryos. Transgenic epidermis developed normal-looking lamellar granules at E16 (Fig. 6b), but when these granules extruded their lipid lamellae at E17, no lamellar structure was formed between the granular cells and the periderm (Fig. 6d). During normal development, formation of the initial lipid multilamellar structure precedes the onset of keratinization, which occurs at E18. However, in transgenic epidermis, the absence of a functional lipid barrier induced the onset of premature cornification at E17 (Fig. 6f), 1 day earlier than normal (DuBrul 1972).

\section{RAR $\alpha 403$ functions as a dominant-negative in keratinocytes}

To confirm that the RAR $\alpha 403$ mutant was in fact functioning as a dominant negative in keratinocytes, we cotransfected primary mouse keratinocytes with a retinoic acid response element reporter $(\Delta-\mathrm{SV}$ - $\beta$ RE2-CAT) and an expression vector encoding the RAR $\alpha 403$ (RSRAR $\alpha 403$ ). Suppression occurred both in the presence and absence of retinoic acid (Fig. 7). This result is in complete agreement with the previous study, which used CV-1 cells /a monkey kidney cell line that is probably of fibroblast origin) and demonstrated the ability of
RAR $\alpha 403$ to inhibit the activity of wild-type RARs (Damm et al. 1993). The ability of RAR $\alpha 403$ to inhibit trans-activation in an unliganded state was also observed in the initial study and is thought to be attributable to unmasking (by removal of carboxy-terminal sequences) of a receptor domain that can bind directly to cognate sites and inhibit transcription (Damm et al. 1993).

Although our transgenic results, implicating the retinoid signaling pathway in modulation of lipid synthesis and processing, are novel for the epidermis, there is precedence for a physiological role for 9-cis retinoic acid in modulating lipid metabolism in the liver. Recent studies have shown the convergence of 9-cis retinoic acid and peroxisome proliferator signaling pathway through heterodimer formation of their receptors, the RXR and PPAR, respectively (Kliewer et al. 1992b; Gearing et al. 1993; Keller et al. 1993a). To examine the potential role of this pathway in generating the phenotypes observed in our HK1-RAR $\alpha 403$ mice, initially we determined whether PPARs were expressed in the epidermis. We designed PCR primers that would recognize conserved regions in all PPAR isoforms (Chen et al. 1993). Reverse transcriptase-PCR analysis revealed a low level of PPAR mRNA in mouse epidermis, as compared to mouse liver (data not shown). We then assayed for the ability of PPARs to trans-activate a peroxisome proliferator response element (PPRE) reporter in mouse keratinocytes 

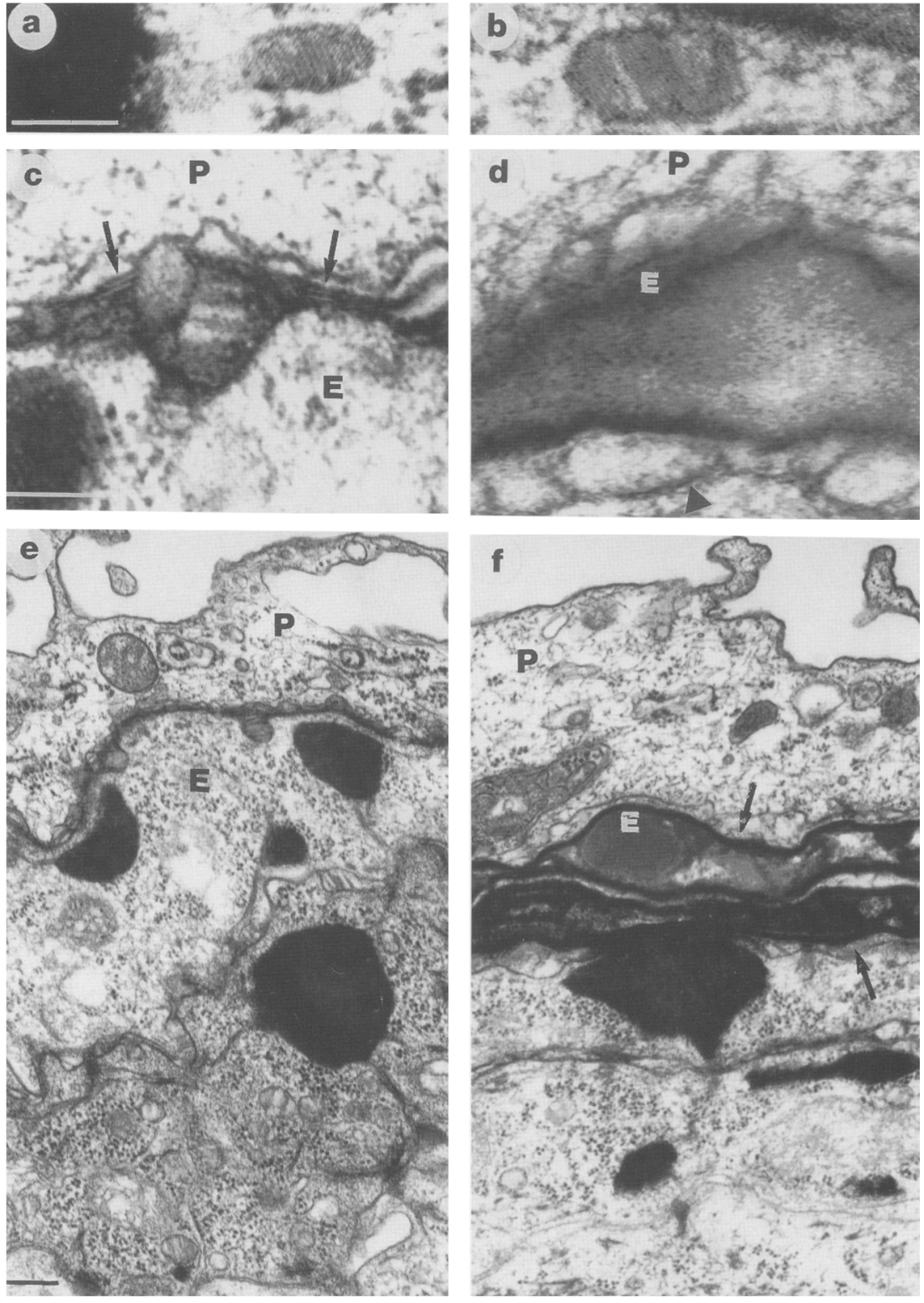

Figure 6. Electron microscopy of normal and HKI-RAR $\alpha 403$ fetal epidermis. Lamellar granules in E16 fetal epidermis from normal $|a|$ and transgenic $(b)$ siblings. Lipid lamellae extruded between epidermal and peridermal cells in E17 fetal epidermis from normal $(c)$ and transgenic $(d)$ siblings; note globular structure (arrowhead in $d$ ) and lack of any lamellar structure (arrows in $c$ ) in transgenic epidermis (d). Upper strata of epidermis from E17 fetal epidermis from normal $(e)$ and transgenic $(f)$ siblings; note premature cornification (arrows) in transgenic epidermis. (P) Periderm; $(E)$ epidermis. Bars, $100 \mathrm{~nm}$.
(Fig. 8). Endogenous PPAR activity was low in proliferating keratinocytes; however, an increase in ligand-dependent PPAR activity was observed in keratinocytes that were induced to differentiate (Fig. 8a). Cotransfection of an expression vector encoding PPAR along with the reporter construct also gave only low levels of activity in proliferating keratinocytes; however, a marked induction occurred in differentiating keratinocytes, both in the presence and, to a lesser extent, in the absence of clofibric acid (Fig. 8b). The RAR $\alpha 403$ mutant was able to inhibit the low level of trans-activation by endogenous PPARs, as well as that resulting from cotransfection with the PPAR expression vector (Fig. 8a,b).

\section{Discussion}

Previous transgenic mouse lines resulting from targeted disruption of the RAR $\alpha$ or RAR $\gamma$ genes (Li et al. 1993; Lohnes et al. 1993; Lufkin et al. 1993/ failed to exhibit a skin phenotype, suggesting functional redundancy among RARs in this tissue. Disruption of the RXR $\alpha$ gene resulted in embryonic lethality between E13.5 and E16.5 (Sucov et al. 1994; Kastner et al. 1994) before formation of a fully functional epidermis. To produce a functional knockout of the retinoid signaling pathway with a single targeting event, we expressed a mutant RAR $\alpha$ (RAR $\alpha 403$ ) that exhibits a broad spectrum of potent dominant-negative activity because of its ability to form inactive heterodimers (Damm et al. 1993). To avoid embryonic lethality, we targeted expression of RAR $\alpha 403$ with an epidermal-specific vector, which is expressed relatively late during mouse development, E15, when the embryonic skin stratifies initially /Greenhalgh et al. 1993a,b; Chung et al. 1994). This approach produced a 


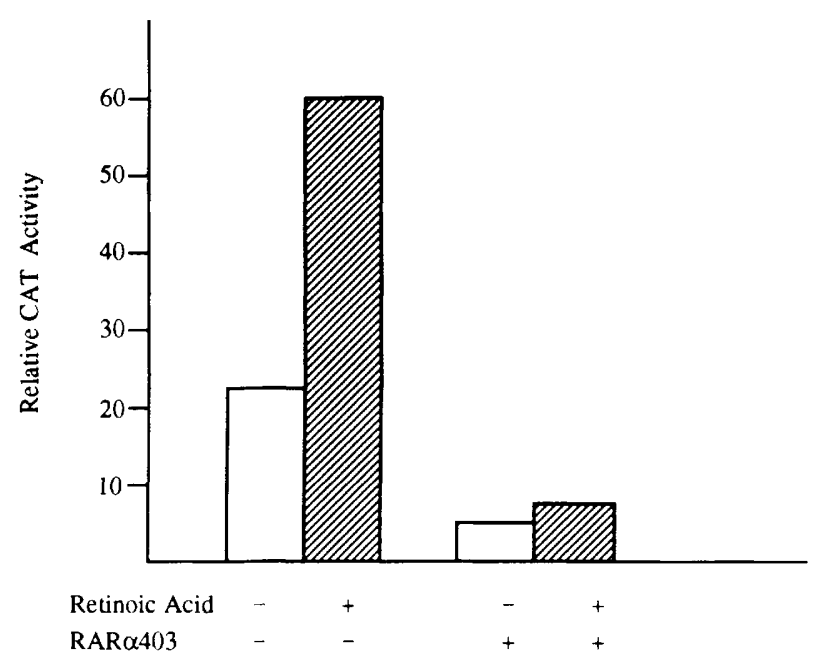

Figure 7. Inhibition of RAR trans-activation by RAR $\alpha 403$ in keratinocytes. Primary mouse keratinocytes were transfected with the reporter gene $\Delta S V-\beta R E 2-C A T$ or $\Delta S V-\beta R E 2-C A T$ and RS-RAR $\alpha 403$. Cells cultured under differentiating (high $\mathrm{Ca}^{2}$ ) conditions were transfected and treated with or without $0.1 \mu \mathrm{M}$ retinoic acid. Cell extracts were prepared and assayed subsequently for chloramphenicol acetyltransferase (CAT) activity. Average values of four independent transfection experiments are shown.

profound skin phenotype that confirms the role of the retinoid signaling pathway in formation and maintenance of a functional epidermis.

The shiny red skin of HK1-RAR $\alpha 403$ pups immediately distinguished them from their unaffected littermates. On the basis of previous in vitro studies demonstrating that retinoids were able to suppress expression of differentiation-specific genes [i.c., K1, K10, loricrin, and filaggrin (Roop et al. 1987; Hohl et al. 1991), we anticipated that inhibition of the retinoid signaling pathway might result in altered, perhaps premature, expression of these genes and this might explain the macroscopic appearance of phenotypic pups. However, histological changes in phenotypic epidermis were subtle and immunofluorescence studies revealed no significant changes in the temporal pattern of expression of these structural proteins. These results were unexpected, but suggest that multiple factors, in addition to retinoids, are involved in regulation of differentiation-specific genes and are consistent with our previous studies demonstrating the involvement of multiple elements in regulating appropriate expression of the human K1 gene (Rosenthal et al. 1991; Chung et al. 1994; Lu et al. 1994).

Inappropriate expression of $\mathrm{K} 6$, a keratin induced in response to a variety of stimuli that perturb normal keratinocyte biology (Sellheyer et al. 1993), was observed, and this occurred at E17, a time during normal development when the epidermis takes over the barrier function from the periderm (DuBrul 1972). Moreover, the expression of K6 was unusual in that it occurred initially in granular cells just beneath the periderm, suggesting a potential defect in epidermal barrier function. This observation prompted an assessment of epidermal barrier function and revealed that phenotypic skin lost water at a rate three times greater than controls.

The barrier function of the epidermis is maintained by the stratum corneum, an important interface between the external and internal environments of vertebrates, and its integrity is essential for survival. The structural components of this layer consist primarily of the $\mathrm{CE}$, which is a cross-linked protein complex, the keratin filament-matrix complex, which is anchored to the inner surface of the $C E$, and the lipid multilamellar structure, which is covalently linked to the outer surface of the CE (Wertz et al. 1989; Hohl and Roop 1993; Reichert et al. 1993). After determining that the protein components of transgenic epidermis were normal, we analyzed the lipid component and discovered that lipid multilamellar structures were not present between cells in the stratum corneum of phenotypic mice. The lipid component of the stratum corneum originates from lamellar granules, membrane-bound organelles that first appear in the spinous layer, increase in number in the granular layer and subsequently, extrude their contents into the intracellular spaces as the cells make their transition to the stratum corneum (Lavker 1976). The extruded lipid bilamellar disks are processed enzymatically and fused into the intercellular multilamellar lipid structures that are covalently linked by ester bonds to the carboxyl groups of the CE (Wertz et al. 1989; Chang et al. 1993). Our developmental studies showed that normal-looking lamellar granules formed at E16; however, when the lipid lamellae were extruded from these granules at E17, no multilamellar structures were formed; only amorphous globs were scen between the granular layer and the periderm. The failure of extruded lipid disks to fuse could be attributed to an altered lipid composition or an absence of hydrolytic enzymes required for processing lipids before their fusion.

Given the broad range of dominant negative activity demonstrated by RAR 403 in previous in vitro studies (Damm et al. 1993), we were surprised that RAR 403 demonstrated apparent selectivity in inhibiting lipid metabolism when targeted to the epidermis in vivo. Although our study provides the first in vivo data implicating the retinoid signaling pathway in modulating lipid metabolism in the epidermis, previous in vitro studies have demonstrated the effects of retinoids in modulating the lipid composition of keratinocytes (for review, see Ponec 1991). The addition of retinoic acid at micromolar concentrations to keratinocytes cultured in retinoic acid-depleted medium, under both submerged and air-exposed conditions, induced marked changes in lipid synthesis (Ponec et al. 1987; Ponec and Boonstra 1987) and in lipid composition (Brod et al. 1991; Ponec 1989). In submerged cultures, the addition of retinoids leads to modulated synthesis of all the major lipid classes (Ponec et al. 1987; Ponec and Boonstra 1987), decreased cholesterol sulfate production (Jetten et al. 1989|, and a complete suppression of acylceramide and lanosterol synthesis (Brod et al. 1991). Although these 


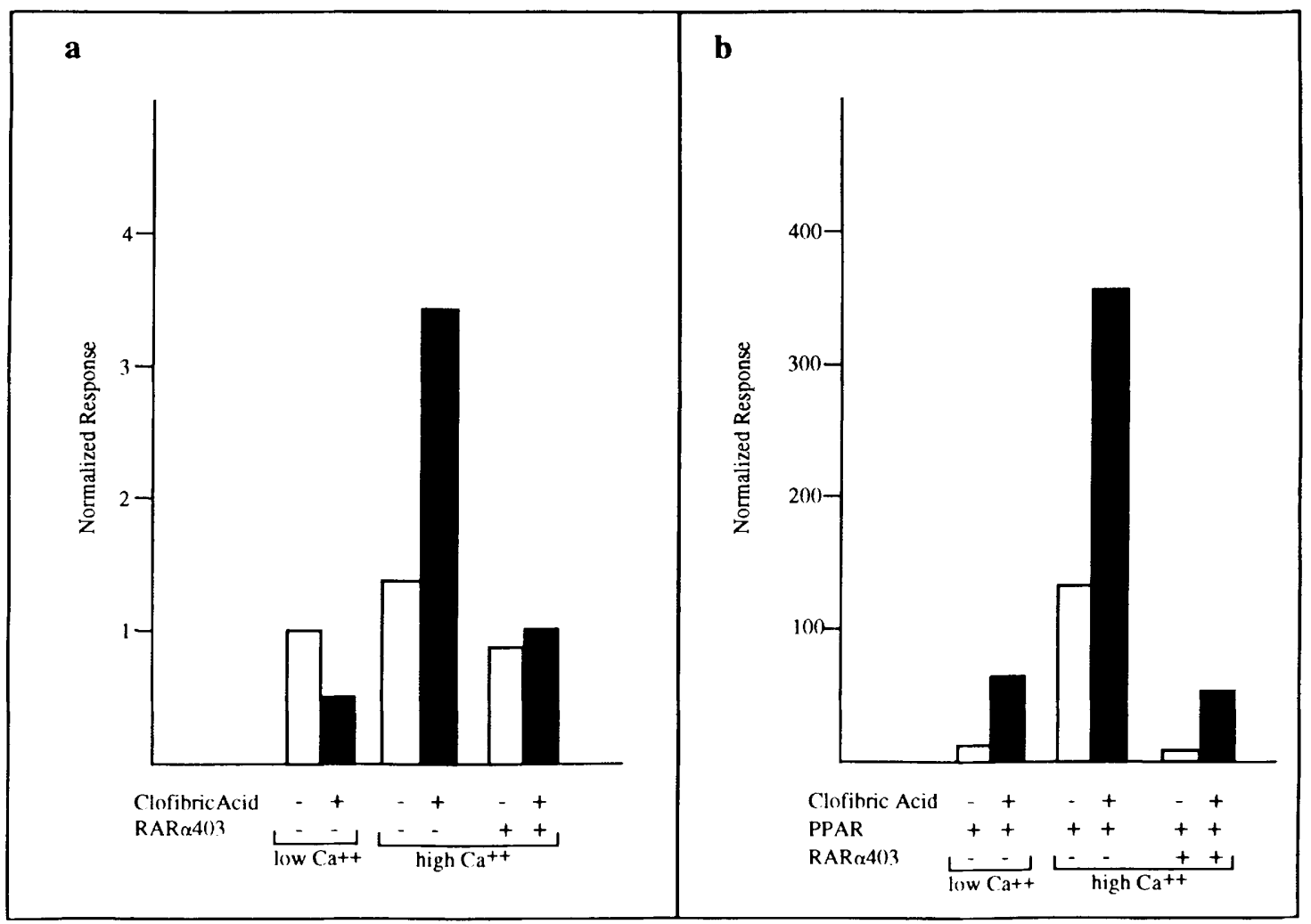

Figure 8. Trans-activation of the peroxisome proliferator reporter in keratinocytes and inhibition of the trans-activation by

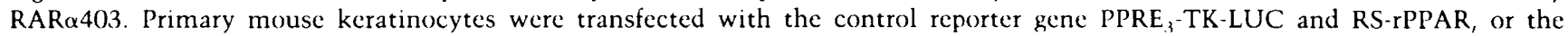
PPRE $_{3}$-TK-LUC, RS-rPPAR, and RS-RAR $\alpha 403$. Cells were cultured under both proliferating (low $\mathrm{Ca}^{2}$ ") and differentiating (high $\mathrm{Ca}^{2+}$ ) conditions. Cell extracts were prepared and assayed subsequently for luciferase activity. $(a)$ Although there is a low amount of endogenous PPAR present, it is activated by clofibric acid in differentiated keratinocytes and this activation is inhibited by RAR 403 . (b) Cotransfection of RS-rPPAR results in a greater response to ligand activation; however, the response is still inhibited by RAR $\alpha 403$. Average values of four independent transfection experiments are shown.

results strongly suggest a role for retinoic acid in modulating the synthesis of lipids that are expressed at late stages of epidermal differentiation, it has been difficult to assess the ultimate consequence of retinoic acid on epidermal barrier function in vitro, as the culture systems, even with recent improvements (Fartasch and Ponec 1994) do not form a permeability barrier equivalent to that synthesized in vivo. Elias et al. (1981) have reported a dose-dependent increase in transepidermal water loss and a loosening of the stratum corneum in mice after treatment with systemic retinoids. Data correlating these observations with changes in lipid composition were not reported; however, on the basis of the in vitro data, these results are consistent with retinoid involvement in lipid metabolism. Interestingly, our transgenic mice show a more loosely packed stratum corneum than normal (see Fig. 2) and when we compared corneocyte adhesion by gently tape stripping neonate skin, the HK1-RAR $\alpha 403$ mice lost three times as many cells as the normal controls (data not shown).

Our transgenic data implicating the retinoid signaling pathway in modulation of lipid synthesis and processing are novel for the epidermis; however, evidence docu- menting the role of 9-cis retinoic acid in modulating lipid metabolism in the liver has been reported (Kliewer et al. 1992b|. In the liver, a group of substances that includes hypolipidemic drugs, such as clofibrate, phthalate ester plasticizers, and trichlorophenoxyacetic acid herbicides, causes peroxisome proliferation and an increase in the activities of several enzymes, especially those associated with peroxisomes and microsomes (for review, see Keller et al. 1993b). PPAR $\alpha$, a member of the nuclear hormone receptor superfamily, was shown to be activated by these agents. In addition to peroxisome proliferators, a variety of fatty acids activate $\operatorname{PPAR} \alpha$, and this receptor has been shown to stimulate expression of the genes encoding rat acyl-CoA oxidase (AOX) and hydratase-dehydrogenase, enzymes required for peroxisomal $\beta$-oxidation, as well as rabbit cytochrome $P 450_{4 \mathrm{~A} 6}$, a fatty acid $\omega$-hydroxylase (Gottlicher et al. 1992; Muerhoff et al. 1992; Tugwood et al. 1992; Bardot et al. 1993; Marcus et al. 1993). These genes contain PPREs, which are bound by heterodimers formed between PPAR $\alpha$ and RXR (Kliewer et al. 1992b; Gearing et al. 1993; Keller et al. 1993b|. Several PPAR $\alpha$-related proteins have been identified in Xenopus and human (Dreyer et al. 1992; 
Schmidt et al. 1992), and recently two additional mouse genes PPAR $\gamma$ (Chen et al. 1993; Zhu et al. 1993; Kliewer et al. 1994) and PPAR (Kliewer et al. 1994) have been described.

The potential role of this pathway in regulating lipid metabolism in the epidermis remains to be determined. We have demonstrated that low levels of PPAR mRNA are present within the epidermis, and although transfection studies with primary mouse keratinocytes and a PPRE reporter construct derived from the AOX gene only revealed a low level of endogenous PPAR activity under proliferating conditions, an increase was observed in differentiating cells. Furthermore, a marked increase in activity was observed when an expression vector encoding PPAR was cotransfected with the PPRE reporter. This only occurred under differentiated conditions and substantial activity was observed in the absence of ligand. There are two potential explanations for these results. First, we did not cotransfect an RXR expression vector in these experiments; therefore, the high level of activity in differentiated cells could be attributable to induction of the endogenous RXR genes. In situ hybridization studies have shown that the RXR $\alpha$ gene is expressed preferentially in the differentiated layers of the epidermis (Mangelsdorf et al. 1992; W. Wong and R. Lotan, pers. comm.). Second, the high activity in the absence of ligand may be attributable to the presence of endogenous ligands, for example, physiological concentrations of either polyunsaturated or monounsaturated fatty acids supplied from either internal stores or serum in the medium could activate PPARs. We also demonstrated that RAR $\alpha 403$ was able to inhibit the low level of trans-activation by endogenous PPARs, as well as that resulting from cotransfection with the PPAR expression vector. We assume that this occurs because of the ability of RAR $\alpha 403$ to bind to and sequester RXR, as previously shown in CV-1 cells (Damm et al. 1993).

Although it has been known for some time that imbalances in vitamin A levels can produce profound skin effects [e.g., thinning of the epidermis or thickening of the stratum corneum (hyperkeratosis) that results in a dry scaly appearance (Davies et al. 1992)], the underlying mechanisms that mediate these changes in the skin are not known. Alterations in epidermal lipogenesis have also been associated with scaling disorders (for review, see Williams 1991). In some cases, inborn errors of lipid metabolism are responsible, whereas others are induced by hypolipidemic drugs, including clofibrate, a ligand that results in activation of PPARs. It is of interest to note that to date all of the genes identified as being regulated by PPARs encode enzymes that hydrolyze fatty acids. Formation of the multilamellar lipid structures between cells in the stratum corneum also requires the activity of hydrolytic enzymes (Wertz and Downing 1992). It is exactly at this stage of epidermal maturation that HK1-RAR $\alpha 403$ mice exhibit a lipid defect, and our preliminary analysis of the lipid composition of phenotypic epidermis is consistent with a defect in lipid processing (data not shown). Therefore, this transgenic model should prove useful in the identification of genes that are regulated directly by retinoids and involved in modulating epidermal lipid metabolism.

\section{Materials and methods \\ Construction of the dominant-negative mutant transgene HK1-RAR $\alpha 403$}

The detailed design and dominant negative nature of RAR $\alpha 403$ were described previously (Damm et al. 1993). The detailed design and epidermal specific expression properties of the $\mathrm{HKl}$ targeting vector has also been reported (Greenhalgh et al. 1993a,b). By using specific oligonucleotides 1 (5'-CCATCGATTGGATCCACCATGGCCAGCAACAGCAGC- $\left.3^{\prime}\right)$ and $2\left(5^{\prime}\right.$ CCATCGATTAGCCCGGGATCTCCATCTTC-3'), a BamHI site was created just $5^{\prime}$ of the start codon of RAR $\alpha 403$ and a stop codon, followed by ClaI site, was introduced after the amino acid 403. The resulting BamHI-Clal fragment was ligated to the HKl targeting vector (Fig. la).

\section{Generation and identification of transgenic mice}

The HK1-RAR $\alpha 403$ transgene was cut from the pGem3 plasmid with EcoRI, isolated by agarose gel electrophoresis, paper purified (NA45 paper, Schleicher \& Schuell), and further purified by ultracentrifugation. The purified DNA was microinjected into the pronuclei of embryos obtained from ICR female mice mated to FVB males. After microinjection, 15-20 embryos were transferred to the oviduct of each ICR pseudopregnant foster mother, as described (Greenhalgh et al. 1993a). After birth, transgenic pups were confirmed by PCR analysis of their DNA using oligonucleotides 3 (5'-GACATGCTGCAGGAGCCG-3' $)$ and $4\left(5^{\prime}\right.$-GAGGTGCTTTGAAATGTCATGTGGG$\left.3^{\prime}\right)$. For the developmental study, normal females were mated with the founder male A7802, and embryos were sacrificed at E14, E15, E16, E17, and E18. PCR-positive embryos and normal littermates were analyzed by immunofluorescence, RNA analysis, and electron microscopy as described below.

\section{Preparation and analysis of RNA}

Skins from newborn transgenic mice were floated on $0.25 \%$ trypsin at $4^{\circ} \mathrm{C}$ for $18 \mathrm{hr}$, after which the epidermis was separated from the underlying dermis as an independent sheet. Total RNA was isolated from the epidermis using the RNAzol (Biotex Labs, TX), and $1 \mu \mathrm{g}$ of total RNA was reverse transcribed with $400 \mathrm{ng}$ of random hexamer at $42^{\circ} \mathrm{C}$ for $2 \mathrm{hr}$, followed by PCR amplification with oligonucleotides 3 and $5\left(5^{\prime}\right.$-CATATTTGTTAGTGATGC-3'). For embryos from E14, E15, E16, and E17, RNAs were extracted from total skin, then treated the same as neonatal epidermal RNA. RNase protection analysis was performed on epidermal RNA from mice exhibiting normal, moderate, and severe phenotypes with a RPA II kit (Ambion) essentially as described previously using a ${ }^{32} \mathrm{P}$-labeled probe specific for the $3^{\prime}$ noncoding region of the HKl targeting vector (Wang et al. 1995).

\section{Immunofluorescence}

To examine the epidermis for expression of differentiation markers, skin samples from both embryos and neonates were embedded in Tissue TekII OCT (Lab-Tek Products, IL) and frozen. Sections of $6-8-\mu \mathrm{m}$ were cut in a cryostat, placed on uncoated slides, and stored at $-80^{\circ} \mathrm{C}$ until needed. A three-step, two-color indirect immunofluorescence was performed by sequential incubation with (1) primary antibodies (rabbit anti-K1, $\mathrm{K} 6$, loricrin, or filaggrin, and guinea pig anti-K14), (2) secondary 
antibodies [sheep anti-rabbit conjugated with FITC (Dakopatts, Denmark)l, and (3) goat anti-guinea pig conjugated with biotin (Vector, CA) and streptavidin Texas red (GIBCO BRL, MD).

\section{Evaluation of epidermal barrier function and TEWL}

The rate of TEWL through isolated neonatal skin was measured using the gravimetric technique described by Vinson et al. (1965). After disassembling the aluminum gravimetric cells, a thin coat of silicone vacuum grease was applied to the surfaces with which the skins would come in contact to facilitate watertight seals. Individual skins were positioned dermis-side down over the cells' center wells that contained $0.5 \mathrm{ml}$ of sterile water, the restraining rings placed over the skins, excess overhanging pieces of skin carefully trimmed, and the upper threaded rings of the cells loosely fastened to the lower halves. The cells were placed in an unevacuated desiccator at room temperature for $24 \mathrm{hr}$, after which they were removed and the upper rings hand-tightened to establish complete seals. Initial weights were taken using an analytical balance, recorded, and the cells placed back in the desiccator. Subsequent weights were taken and recorded $24,48,72$, and $96 \mathrm{hr}$ later. The rates of transepidermal moisture loss through the skins (in $\mathrm{mg} / \mathrm{cm}^{2} / \mathrm{hr}$ ) were calculated by dividing the change in each cell's weight (in $\mathrm{mg}$ ) by the product of 0.775 (the area of the center well in $\mathrm{cm}^{2}$ ) times the number of hours between weighings.

\section{Electron microscopy}

Pieces of tissuc to be examined for lipid structure were processed according to Madison ct al. (1987) with slight modification. Briefly, neonatal and embryonic skin were fixed $20 \mathrm{hr}$ at $4^{\circ} \mathrm{C}$ in half-strength Karnovsky's fixative (Karnovsky 1965), rinsed in $0.1 \mathrm{M}$ cacodylate buffer, postfixed $30 \mathrm{~min}$ at room temperature in the dark in either $0.2 \%$ ruthenium tetroxide with $0.5 \%$ potassium ferrocyanide in $0.1 \mathrm{M}$ cacodylate buffer or in $1 \% \mathrm{OsO}_{4}$ with $0.5 \%$ potassium ferrocyanide in $0.1 \mathrm{M}$ cacodylate buffer, dehydrated through a graded series of ethanols, and embedded in EMbed 812 (Electron Microscopy Sciences, PA). Sections were cut at $1 \mu \mathrm{m}$ and stained with Richardson's stain (Richardson et al. 1960) for light microscopy and cut at 60 $\mathrm{nm}$ and stained in uranyl acetate and lead citrate for electron microscopy.

\section{Transfection of primary mouse keratinocytes}

Mouse primary keratinocytes were transfected with $33.5 \mu \mathrm{g}$ of DNA per dish, including $2.5 \mu \mathrm{g}$ of PREA $_{3}$-tk-LUC, together with $1 \mu \mathrm{g}$ of RS-rPPAR and $7.5 \mu \mathrm{g}$ of RS-RAR $\alpha 403$ as indicated (the total amount of RS-expression plasmid was maintained constant in each transfection through the addition of Rouse sarcoma virus- $\beta$ gal; $22.5 \mu \mathrm{g}$ of salmon sperm DNA was used as carrier DNA). Clofibric acid was added to a final concentration of $1 \mathrm{~mm}$. Cells were harvested 3 days after transfection and cell extracts were assayed for luciferase activity. Each luciferase activity was normalized to protein concentration, and the luciferase activity, derived from transfection without RS-rPPAR, RS-RAR $\alpha 403$, or clofibric acid, was defined as an arbitrary unit of 1 .

In addition, keratinocytes were transfected with $30 \mu \mathrm{g}$ of either RS-RAR $\alpha 403$, which contains the Rous sarcoma virus promoter driving the human RAR $\alpha 403$ mutant, or salmon sperm DNA together with $5 \mu \mathrm{g}$ of the reporter gene $\triangle \mathrm{SV}-\beta \mathrm{RE} 2-\mathrm{CAT}$, which contains the retinoic acid response element in the promoter region of the RAR $\beta$ gene. Both sets of cells were cultured under differentiating conditions (high $\mathrm{Ca}^{2+}$ ) and grown with and without $0.1 \mu \mathrm{M}$ all-trans-retinoic acid added to the medium. Cell extracts were assayed subsequently for CAT activity.

\section{Acknowledgments}

We thank Drs. Peter Davies and Gregor Eichele for comments on the manuscript and N.J. Laminack for its preparation. S.I. was a visiting research associate sponsored by Shiseido Co., Ltd. and a Uehara Memorial Postdoctoral Fellowship; J.A.R. was the recipient of a Dermatology Foundation Career Development Award sponsored by Ortho Pharmaceuticals, Inc. This work was supported, in part, by National Institutes of Health award AR40240 to D.R.R.

The publication costs of this article were defrayed in part by payment of page charges. This article must therefore be hereby marked "advertisement" in accordance with 18 USC section 1734 solely to indicate this fact.

\section{References}

Bardot, O., T.C. Aldridge, N. Latruffe, and S. Green. 1993. PPAR-RXR heterodimer activates a peroxisome proliferator response element upstream of the bifunctional enzyme gene. Biochem. Biophys. Res. Commun. 192: 37-45.

Brand, N., M. Petkovich, A. Krust, P. Chambon, H. de The, H. Marchio, P. Tiollais, and A. Dejean. 1988. Identification of a second human retinoic acid receptor. Nature 332: 850-853.

Brod, J., E. Bavelier, P. Justine, A. Weeheim, and M. Ponec. 1991. Acylceramides and lanosterol-lipid markers of terminal differentiation in cultured human keratinocytes: Modulating effect of retinoic acid. In Vitro Cell Dev. Biol. 27A: 163-168.

Chang, F., D.C. Swartzendruber, P.W. Wertz, K.C. Madison, and D.T. Downing. 1993. Covalently bound lipids in keratinizing epithelia. Biochem. Biophys. Acta 1150: 98-102.

Chen, F., S.W. Law, and B.W. O'Malley. 1993. Identification of two mPPAR related receptors and evidence for the existence of five subfamily members. Biochem. Biophys. Res. Commun. 196: 67l-677.

Chung, S.Y., C.K. Cheng, J.A. Rothnagel, S.H. Yu, H. Nakazawa, T. Mehrel, D. Hohl, D.S. Rosenthal, P.M. Steinert, S.H. Yuspa, and D.R. Roop. 1994. Expression of the human keratin gene $(K 1)$ in transgenic mice is tissue- and developmental-specific but altered with respect to differentiation state. Mol. Cell. Differentiation 2: 61-81.

Damm, K., R A. Umesono, and R.M. Evans. 1993. Functional inhibition of retinoic acid response by dominant negative retinoic acid receptor mutants. Proc. Natl. Acad. Sci. 90: $2989-2993$.

Davies, P.J.A., J.P. Basilion, and A.R. Haake. 1992. Intrinsic biology of retinoids in the skin. In Physiology, biochemistry, and molecular biology of the skin (ed. L.A. Goldsmith), pp. 385-409. Oxford University Press, New York.

Dominey, A.M., X.-J. Wang, L.E. King, L.A. Nanny, T.A. Gagne, K. Sellheyer, D.S. Bundman, M.A. Longley, J.A. Rothnagel, D.A. Greenhalgh, and D.R. Roop. 1993. Targeted over-expression of TGFa in the epidermis of transgenic mice elicits anomalous epidermal differentiation and spontaneous, squamous papillomas. Cell Growth Differ. 4: 1071-1081.

Dreyer, C., G. Krey, H. Keller, F. Givel, G. Helftenbein, and W. Wahli. 1992. Control of the peroxisomal beta-oxidation pathway by a novel family of nuclear hormone receptors. Cell 68: 879-887.

DuBrul, E. 1972. Fine structure of epidermal differentiation in the mouse. I. Exp. Zool. 181: 145-158.

Elder, J.T., G. J. Fisher, Q.-Y. Zhang, D. Eisen, A. Krust, P. Kast- 
ner, P. Chambon, and J.J. Voorhees. 1991. Retinoic acid receptor gene expression in human skin. I. Invest. Dermatol. 96: $425-433$.

Elias, P.M. and D.S. Friend. 1975. The permeability barrier in mammalian epidermis. J. Cell Biol. 65: 180-191.

Elias P.M., P.O. Fritsch, M. Lampe, M.L. Williams, B.E. Brown, M. Nemanic, and S. Grayson. 1981. Retinoid effects on epidermal structure, differentiation, and permeability. Lab. Invest. 44: 531-540.

Evans, R. 1988. The steroid and thyroid hormone receptor superfamily. Science 240: $889-895$

Fartasch M. and M. Ponec. 1994. Improved barrier structure formation in air-exposed human keratinocyte culture systems. I. Invest. Dermatol. 102: 366-374.

Fuchs, E. and H. Green. 1981. Regulation of terminal differentiation of cultured human keratinocytes by vitamin A. Cell 25: 617-625.

Gearing, K.L., M. Gottlicher, M. Teboul, and J.A. Gustafsson. 1993. Interaction of the peroxisome-proliferator-activated receptor and retinoid X receptor. Proc. Natl. Acad. Sci. 90: $1440-1444$.

Giguere, V., E.S. Ong, P. Segui, and R.M. Evans. 1987. Identification of a receptor for the morphogen retinoic acid. Nature 330: 624-629.

Gottlicher, M., E. Widmark, Q. Li, and J.A. Gustafsson. 1992. Fatty acids activate a chimera of the clofibric acid-activated receptor and the glucocorticoid receptor. Proc. Natl. Acad. Sci. 89: 4653-4657.

Green, H. and F.M. Watt. 1982. Regulation by vitamin A of envelope cross-linking in cultured keratinocytes derived from different human epithelia. Mol. Cell Biol. 2: 11151117.

Green S. and P. Chambon. 1988. Nuclear receptors enhance our understanding of transcription regulation. Trends Genet. 4: 309-314.

Greenhalgh, D.A., J.A. Rothnagel, I.M. Quintanilla, C. Orengo, T.A. Gagne, D.S. Bundman, M.A. Longley, and D.R. Roop. 1993a. Targeted expression of $\mathrm{v}$-ras ${ }^{\mathrm{Ha}}$ to the epidermis of transgenic mice induces hyperplasia, hyperkeratosis and papillomas. Mol. Carcinog. 7:99-110.

Greenhalgh, D.A., J.A. Rothnagel, X.-J. Wang, M.I. Quintanilla, C.C. Orengo, T.A. Gagne, D.S. Bundman, M.A. Longley, C. Fisher, and D.R. Roop. 1993b. Hyperplasia, hyperkeratosis and benign tumor production in transgenic mice by a targeted $\mathrm{v}$-fos oncogene suggest a role for fos in epidermal differentiation and neoplasia. Oncogene 8: 2145-2157.

Heyman, R.A., D.J. Mangelsdorf, J.A. Dyck, R.B. Stein, G. Eichele, R.M. Evans, and C. Thaller. 1992. 9-Cis retinoic acid is a high affinity ligand for the retinoic $\mathrm{X}$ receptor. Cell 68: $397-406$.

Hohl, D. and D.R. Roop. 1993. Loricrin: Molecular biology of the skin: The keratinocyte (ed. M. Darmon and M. Blumenbergl, pp. 151-179, Academic Press, San Diego, CA.

Hohl, D., U. Lichti, D. Breitkreutz, P.M. Steinert, and D.R. Roop. 1991. Transcription of the human loricrin gene in vitro is induced by calcium and cell density and suppressed by retinoic acid. I. Invest. Dermatol. 96: 414-418.

Jetten, A.M., M.A. George, C. Nerri, L.R. Boone, and J.I. Rearick. 1989. Increased cholesterol sulfotransferase activity in relation to the multi-step process of differentiation in human epidermal keratinocytes. J. Invest. Dermatol. 92: 203-209.

Karnovsky, M.J. 1965. A formaldehyde-glutaraldehyde fixative of high osmolarity for use in electron microscopy. I. Cell Biol. 27: 137A-138A.

Kastner, P., J.M. Grondona, M. Mark, A. Gansmuller, M. LeMeur, D. Decimo, J.-L. Vonesch, P. Dolle, and P. Cham- bon. 1994. Genetic analysis of RXR $\alpha$ developmental function: Convergence of RXR and RAR signaling pathways in heart and eye morphogenesis. Cell 78: 987-1003.

Keller, H., C. Dreyer, J. Medin, A. Mahfoudi, K. Ozato, and W. Wahli. 1993a. Fatty acids and retinoids control lipid metabolism through activation of peroxisome proliferator-activated receptor-retinoid $\mathrm{X}$ receptor heterodimers. Proc. Natl. Acad. Sci. 90: 2160-2164.

Keller, H., A. Mahfoudi, C. Dreyer, A.K. Hihi, J. Medin, K. Ozato, and W. Wahli. 1993b. Peroxisome proliferator-activated receptors and lipid metabolism. Ann. N.Y. Acad. Sci. 684: 157-173.

Kliewer, S.A., K. Umesono, D.J. Mangelsdorf, and R.M. Evans. 1992a. Retinoid X receptor interacts with nuclear receptors in retinoic acid, thyroid hormone and vitamin $\mathrm{D}_{3}$ signalling. Nature 355: 446-449.

Kliewer, S.A., K. Umesono, D.J. Noonan, R.A. Heyman, and R.M. Evans. 1992b. Convergence of 9-cis retinoic acid and peroxisome proliferator signalling pathways through heterodimer formation of their receptors. Nature 358: 771-774.

Kliewer S.A., B.M. Forman, B. Blumberg, E.S. Ong, U. Borgmeyer, D.J. Mangelsdorf, K. Umesono, and R.M. Evans. 1994. Differential expression and activation of a family of murine peroxisome proliferator-activated receptors. Proc. Natl. Acad. Sci. 91: 7355-7359.

Lavker, R.M. 1976. Membrane coating granules: The fate of the discharged lamellae. J. Ultrastruct. Res. 55: 79-86.

Leid, M., P. Kastner, R. Lyons, H. Nakshatri, M. Saunders, T. Zacharewski, J.-Y. Chen, A. Staub, J.-M. Garnier, S. Mader, and P. Chambon. 1992. Purification, cloning, and RXR identity of the HeLa cell Factor with which RAR or TR heterodimerizes to bind target sequences efficiently. Cell 68: $377-395$.

Levin, A.A., L.J. Sturzenbecker, S. Kazmer, T. Bosakowski, C. Nuselton, G. Allen, J. Speck, C. Kratzeisen, M. Rosenberger, and A. Lovey. 1992. 9-Cis retinoic acid stereoisomer binds and activates the nuclear receptor RXR alpha. Nature 355: 359-361.

Li, E., H.M. Sucov, K.-F. Lee, R.M. Evans, and R. Jaenisch. 1993. Normal development and growth of mice carrying a targeted disruption of the $\alpha 1$ retinoic acid receptor gene. Proc. Natl. Acad. Sci. 90: 1590-1594.

Lohnes, D., P. Kastner, V. Dierich, M. Mark, M. LeMeur, and P. Chambon. 1993. Function of retinoic acid receptor in the mouse. Cell 73: 643-658.

Lu, B., J.A. Rothnagel, M.A. Longley, S.Y. Tsai, and D.R. Roop. 1994. Differentiation-specific expression of human keratin 1 is mediated by a composite AP-1/steroid hormone element. I. Biol. Chem. 269: 7443-7449.

Lufkin, T., D. Lohnes, V. Mark, A. Dierich, P. Gorry, M.P. Gaub, M. LeMeur, and P. Chambon. 1993. High postnatal lethality and testis degeneration in retinoic acid receptor $\alpha$ mutant mice. Proc. Natl. Acad. Sci. 90: 7225-7229.

Madison K.C., D.C. Swartzendruber, P.W. Wertz, and D.T. Downing. 1987. Presence of intercellular lipid lamellae in the upper layers of the stratum corneum. I. Invest. Dermatol. 88: 714-718.

Mangelsdorf, D.J., E.S. Ong, J.A. Dyck, and R.M. Evans. 1990. Nuclear receptor that identifies a novel retinoic acid response pathway. Nature 345: 224-229.

Mangelsdorf, D.J., U. Borgmeyer, R.A. Heyman, J.Y. Zhou, E.S. Ong, A.E. Oro, A. Kakizuka, and R.M. Evans. 1992. Characterization of three RXR genes that mediate the action of 9-cis retinoic acid. Genes \& Dev. 6: 329-344.

Marcus, S.L., K.S. Miyata, B. Zhang, S. Subramani, J.P. Capone, and R.A. Rachubinski. 1993. Diverse peroxisome prolifera- 
tor-activated receptors bind to the peroxisome proliferatorresponsive elements of the rat hydratase/dehydrogenase and fatty acyl-CoA oxidase genes but differentially induce expression. Proc. Natl. Acad. Sci. 90: 5723-5727.

Marks, M.S., P.L. Hallenbeck, T. Nagata, J.H. Segars, E. Appella, V.M. Nikodem, and K. Ozato 1992. H-2RIIBP (RXR beta) heterodimerization provides a mechanism for combinatorial diversity in the regulation of retinoic acid and thyroid hormone responsive genes. EMBO \% 11: 1419-1435.

Mehrel, T., D. Hohl, J.A. Rothnagel, M.A. Longley, D. Bundman, C. Cheng, U. Lichti, M.E. Bisher, A.C. Steven, P.M. Steinert, S.H. Yuspa, and D.R. Roop. 1990. Identification of a major keratinocyte cell envelope protein, loricrin. Cell 61: 1103-1112.

Muerhoff, A.S., K.J. Griffin, and E.F. Johnson. 1992. The peroxisome proliferator-activated receptor mediates the induction of CYP4A6, a cytochrome p450 fatty acid omega-hydroxylase, by clofibric acid. I. Biol. Chem. 267: 19051-19053.

Nischt R., D.R. Roop, T. Mehrel, S.H. Yuspa, M. Rentrop, H. Winter, and J. Schweizer. 1988. Aberrant expression during two-stage mouse skin carcinogenesis of a type I $47-\mathrm{kDa}$ keratin, K13, normally associated with terminal differentiation of internal stratified epithelia. Mol. Carcinog. 1: 96-108.

Petkovich, M., N.J. Brand, A. Krust, and P. Chambon. 1987. A human retinoic acid receptor which belongs to the family of nuclear receptors. Nature 330: 444-450.

Ponec, M. 1989. Retinoid-induced modulation of differentiation, keratin and lipid composition in reconstructed epidermis in vitro. In Pharmacology of retinoids in the skin led. U. Reichert and B. Shroot), pp. 45-51. Karger, Basel, Switzerland.

. 1991. Lipid metabolism in cultured keratinocytes Adv. Lipid Res. 24: 8.3-118.

Ponec, M. and J. Boonstra. 1987. Effects of retinoids and hydrocortisone on keratinocyte differentiation, epidermal growth factor binding and lipid metabolism. Dermatologica (Suppl. 1) 175: 67-72

Ponec, M., A. Weerheim, L. Havekes, and J. Boonstra. 1987. Effects of retinoids on differentiation, lipid metabolism, epidermal growth factor, and low-density lipoprotein binding in squamous carcinoma cells. Exp. Cell Res. 171: 426-435.

Reichert, V., S. Michel, and R. Schmidt. 1993. The cornified envelope: A key structure of terminally differentiating keratinocytes: Molecular biology of the skin (ed. M. Darmon and M. Blumenberg|, pp. 107-150. Academic Press, San Diego, CA.

Richardson K.C., L. Jarrett, and E.H. Finke. 1960. Embedding in epoxy resin for ultrathin sectioning in election microscopy. Stain Technol. 35: 313-323.

Roop, D.R., H. Huitfeldt, A. Kilkenny, and S.H. Yuspa. 1987. Regulated expression of differentiation-associated keratins in cultured epidermal cells detected by monospecific antibodies to unique peptides of mouse epidermal keratins. Differentiation 35: 143-150.

Rosenthal, D.S., P.M. Steinert, S. Chung, C.A. Huff, J. Johnson, S.H. Yuspa, and D.R. Roop. 1991. A human epidermal differentiation-specific keratin gene is regulated by calcium but not negative modulators of differentiation in transgenic mouse keratinocytes. Cell Growth Differ. 2: 107-113.

Rosenthal, D.S., C.E.M. Griffiths, S.H. Yuspa, D.R. Roop, and J.J. Voorhees. 1992. Acute or chronic topical retinoic acid treatment of human skin in vivo alters the expression of epidermal transglutaminase, loricrin, involucrin, filaggrin, and keratins 6 and 13 but not keratins 1, 10, and 14. J. Invest. Dermatol. 98: 343-350.

Schmidt, A., N. Endo, S.J. Rutledge, R. Vogel, D. Shinar, and
G.A. Rodan. 1992. Identification of a new member of the steroid hormone receptor superfamily that is activated by a peroxisome proliferator and fatty acids. Mol. Endocrinol. 6: 1634-1641.

Sellheyer, K., J.R. Bickenbach, J.A. Rothnagel, D. Bundman, M.A. Longley, T. Krieg, N.S. Roche, A.B. Roberts, and D.R. Roop. 1993. Inhibition of skin development by overexpression of transforming growth factor $\beta 1$ in the epidermis of transgenic mice. Proc. Natl. Acad. Sci. 90: 5237-5241.

Smith, K.B. 1973. The proteins of the embryonic chick epidermis II. During culture in serum-containing medium with and without added vitamin A. Dev. Biol. 30: 263-278.

Steinert, P.M. 1993. Structure, function, and dynamics of keratin intermediate filaments. I. Invest. Dermatol. 100: 729 734.

Sucov H.M., E. Dyson, C.L. Gumeringer, J. Price, K.R. Chien, and R.M. Evans. 1994. RXR $\alpha$ mutant mice establish a genetic basis for vitamin A signaling in heart morphogenesis. Genes \& Dev. 8: 1007-1018.

Tugwood, J.D., I. Isseman, R.G. Anderson, K.R. Bundell, W.L. MacPheat, and S. Green. 1992. The mouse peroxisome proliferator activated receptor recognizes a response element in the $5^{\prime}$ flanking sequence of the rat acyl CoA oxidase gene. EMBO /. 11: 433-439.

Vinson L.J., E.J. Singer, W.R. Koebler, M.D. Lehman, and T. Masurat. 1965. The nature of the epidermal barrier and some factors influencing skin permeability. Tox. Appl. Pharm. Suppl. 7: 7-19.

Wang, X.-J., D.A. Greenhalgh, X.-R. Lu, J.R. Bickenbach, and D.R. Roop. 1995. TGF $\alpha$ and $v$-fos cooperation in transgenic mouse epidermis induces aberrant keratinocyte differentiation and stable, autonomous papillomas, Oncogene (in press).

Weiss, R.A., R. Eichner, and T.-T. Sun. 1984. Monoclonal antibody analysis of keratin expression in epidermal diseases: A 48- and 56-kdalton keratin as molecular markers for hyperproliferative keratinocytes. /. Cell Biol. 98: 1397-1406.

Wertz, P.W. and D.T. Downing. 1992. Epidermal lipids: Physiology, biochemistry, and molecular biology of the skin (ed. L.A. Goldsmith). Oxford University Press, New York.

Wertz, P.W., K.C. Madison, and D.T. Downing. 1989. Covalently bound lipids of human stratum corneum, $I$. Invest. Dermatol. 92: 109-111.

Williams, M.L. 1991. Lipids in normal and pathological desquamation, $A d v$. Lipid Res. 24: 211-262.

Wolbach S.B. and P.R. Howe. 1925. Tissue changes following deprivation of fat-soluble A vitamin. /. Exp. Med. 42: 753777.

Yu, V.C., C. Delsert, B. Andersen, J.M. Holloway, O.V. DeVary, A.M. Naar, S.Y. Kim, J.M. Boutin, C.K. Glass, and M.G. Rosenfeld. 1991. RXR beta: A coregulator that enhances binding of retinoic acid, thyroid hormone, and vitamin $D$ receptors to their cognate response elements. Cell 67: 12511266.

Yuspa S.H. and C.C. Harris. 1974. Altered differentiation of mouse epidermal cells treated with retinyl acetate in vitro. Exp. Cell Res. 86: 95-105.

Zhang, X.-K., B. Hoffmann, P.B-V. Tran, G. Graupner, and M. Pfahl. 1992. Retinoid X receptor is an auxiliary protein for thyroid hormone and retinoic acid receptors. Nature 355: 441-446.

Zhu, Y., K. Alvares, Q. Huang, M.S. Rao, and J.K. Reddy. 1993. Cloning of a new member of the peroxisome proliferatoractivated receptor gene family from mouse liver. I. Biol. Chem. 268: 26817-26820. 


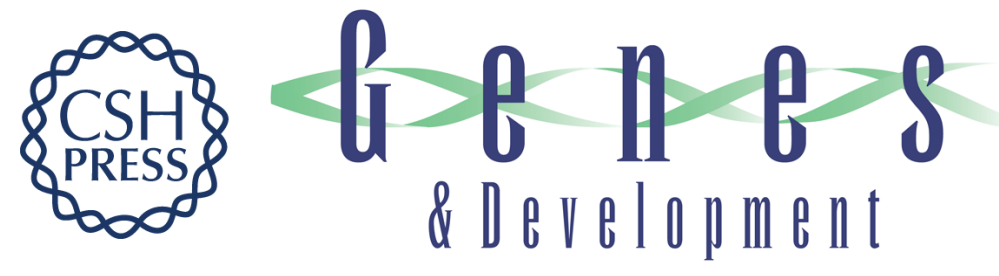

\section{Targeting expression of a dominant-negative retinoic acid receptor mutant in the epidermis of transgenic mice results in loss of barrier function.}

S Imakado, J R Bickenbach, D S Bundman, et al.

Genes Dev. 1995, 9:

Access the most recent version at doi:10.1101/gad.9.3.317

References This article cites 71 articles, 21 of which can be accessed free at: http://genesdev.cshlp.org/content/9/3/317.full.html\#ref-list-1

License

Email Alerting Service

Receive free email alerts when new articles cite this article - sign up in the box at the top right corner of the article or click here.

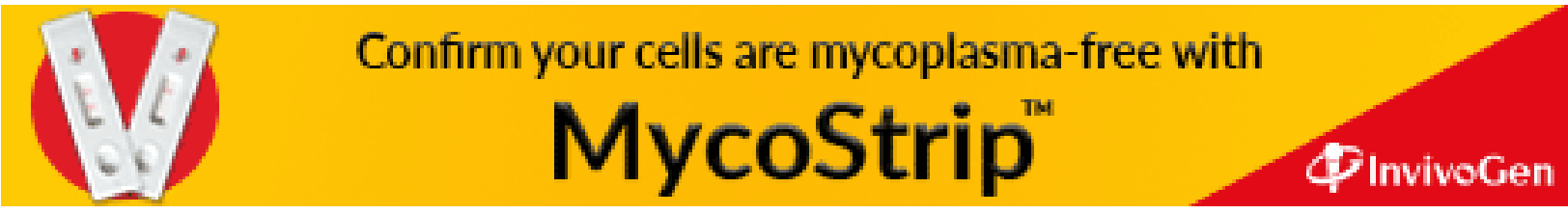

